\title{
A Solid Waste Pond Tiger Shrimp (Peneaus monodon) as Fertilizer for Caulerpa lentillifera
}

\author{
Nyoman Robby Manik Saputra ${ }^{1 *}$, Sukoso ${ }^{2}$, Hartati Kartikaningsih ${ }^{2}$ \\ ${ }^{1}$ Master Program of Aquaculture, Faculty of Fisheries and Marine Sciences, University of Brawijaya, Malang, Indonesia \\ ${ }^{2}$ Faculty of Fisheries and Marine Sciences, University of Brawijaya, Malang, Indonesia
}

\begin{abstract}
Farming the shrimp, fish and another comodity could produce large quantities of waste. Aquaculture waste can be formed as feces, residual feed and dead organism which are accumulated in a cultivation area. Generally, the waste is discharged directly into the water without filtration. Thus, one of problems that are often faced by farmer is the low quality of pure water due to the high content of nutrients. Moreover, suspended solid pollutant will be formed that lead to eutrophication, oxygen depletion, and precipitation. The aim of this research is to analyze the solid waste pond tiger shrimp as fertilizer for the growth of Caulerpa lentiilifera. Here, the Random Design complete (RAL) and three times in Deuteronomy are used in the experiment. The parameters of one control and three treatment doses are used $0,2,4$, and $6{\mathrm{~g} . \mathrm{L}^{-1}}^{-1}$ respectively. The results showed that solid waste shrimp ponds can be used as fertilizer to meet the needs of Caulerpa lentillifera for growth and the results show the highest value is found in the dose of $6 \mathrm{~g} \cdot \mathrm{L}^{-1}$ with $\mathrm{NO}_{3}^{-}(4.58$ $\mathrm{ppm}), \mathrm{NH}_{4}^{+}(3.34 \mathrm{ppm}), \mathrm{PO}_{4}{ }^{3-}(2.03 \mathrm{ppm})$ and the value of the rate of growth and the $\mathrm{PH}$ are obtained $\left(3.64 \mathrm{~g}^{-}\right.$day $\left.^{-1}\right)$ and $(6,4-8)$, respectively.
\end{abstract}

Keywords: Caulerpa lentillifera, growth rate, Nitrification, solid waste, Tiger Shrimp.

\section{INTRODUCTION}

Aquaculture waste is waste generated from a shrimp or fish farming that can cause pollution in the aquatic environment if not immediately addressed. Cultivation of waste could be remnants of the digestion of fish or shrimp or leftover feed that settles on the bottom. The amount of waste goes to the water is linear to the production obtained. The waste could cause environmental problems, related to the magnitude of the amount of nitrogen $(N)$ and phosphorus (P) which are dumped into waterways [1]. For instance, farmed shrimp in Australia estimate the amount of $\mathrm{N}$ and $\mathrm{P}$ produced was 290 and 16 kg.ha year $^{-1}$. Whereas farmed shrimp in California estimate the amount of $\mathrm{N}$ and $\mathrm{P}$ produced amounted to 112 and 32 kg.ha ${ }^{-1}$ year $^{-1}$ [2]. While the amount in Indonesia, $\mathrm{N}$ and $\mathrm{P}$ produced from intensive and traditional ponds reached 399 and $37 \mathrm{~kg}$. ha ${ }^{-1}$ year $^{-1}$ [3].

To overcome this problem, this research focused on making a fertilizer using the solid waste of shrimp. Since the solid waste ponds of shrimp contains $1.92 \%$ organic C, $0.54 \% \mathrm{~N}$ total, and $1.70 \% \mathrm{P}$ [4]. Moreover, the solid waste can be used by plants to grow as organic fertilizer, since

\footnotetext{
* Correspondence author:

Nyoman Robby Manik Saputra

Email : roby.manik.sc@gmail.com

Address : Faculty of Fisheries and Marine Sciences, University of Brawijaya, Jl. Veteran Malang, 65145
}

plants need $\mathrm{NH}_{4}{ }^{+}$and $\mathrm{NH}_{3}{ }^{-}$amino acid in the formation. In his role as fertilizer, solid waste ponds shrimp will be used for cultivating Caulerpa lentiilifera.

Caulerpa lentiilifera is often called the sea grape is a type of seaweed green (Chlorophyta) that can survive in environments that have high pollution levels [5]. Cultivation of $C$. lentillifera has started developing in indonesia, because it can be eaten fresh and also it rich of nutrients that are good for the human body. This sea grape type can also be used as ingredients in cosmetics and pharmaceuticals. In addition, Sea grape types of $C$. lentillifera are highly favored by some countries such as Japan, Australia, and Fillipina [6].

The idea of this research is based on nitrification process. Nitrification is the process by which ammonia is converted to nitrites and then nitrates by the assistance of Nitrosomonas and Nitrobacter bacteria under aerobic conditions. The conversion process of organic material by heterotrophic bacteria in the laboratory has occurred within 1-2 days, while nitrification and De-nitrification process lasts for 2-6 days [7]. Microbes decompose organic matter in the system, causing an increase in the value of TAN (Total Ammonia Nitrogen) and nitrite, are both harmful for fish even at low concentrations [8]. TAN presence in the system can be changed to nitrite, nitrate and nitrogen 
gas [9]. Formation of nitrogen gas is considered negligible in pond aquaculture [10]. The bacteria present in the water and sediment to transform nitrogen through nitrification and denitrification [11]. Thus, this study aims to grow C. lentillifera by analyzing the content of nitrate, ammonium and phosphate in solid waste of tiger shrimp pond (Peneaus monodon) to be used as fertilizer.

\section{MATERIALS AND METHODS}

The research flow of this paper can be seen in the Figure 1.

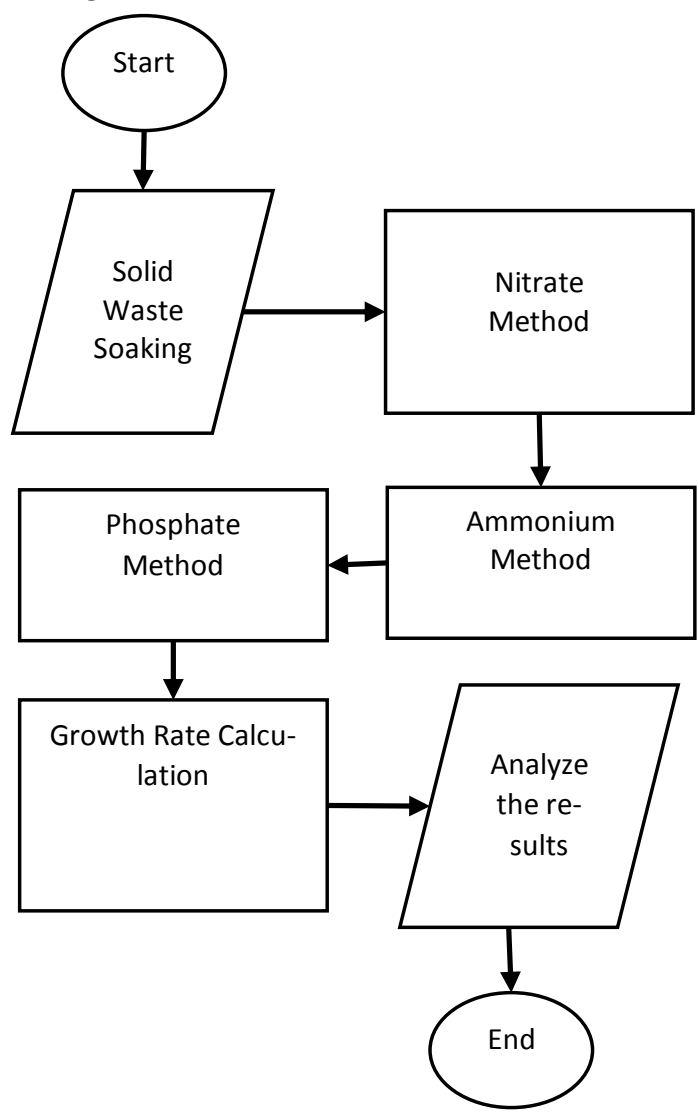

Figure 1. The research flow

\section{Solid Waste Soaking}

Solid wastes were obtained from BBPBAP (Balai Besar Perikanan Budidaya Air Payau) Jepara. The waste was taken at the time of recirculation process in the ponds by using Multi Cylone 16. Then, the waste was dried. After that, the dried solid waste was weighed according to the dosage that will be used in this research, which are 0 g. $L^{-1}, 2$ g. $L^{-1}, 4$ g. $L^{-1}$, and 6 g. $L^{-1}$. Administration of doses [12] has been modified.

Waste that had already been weighed would be soaked in the controlled tub (aquarium) that already contained sea water, then it was left for
48 hours to observe the content of nitrification [4].

\section{Nitrate Method}

The method of Nitrate analysis was appropriate [13], $12.5 \mathrm{~mL}$ water samples were taken and put in a porcelain cup. The sample waters were heated using hot plate until the crust appeared on the porcelain cup. Fenoldisulfonik acid solution of $1 \mathrm{ml}$ were added to the crusted porcelain cup. After that, $2 \mathrm{ml}$ of distilled waters were added into a porcelain cup and then the crust on a porcelain plate was scraped with a spatula. $\mathrm{NH}_{4} \mathrm{OH}$ solution was added to the porcelain cup until the crust turned into stable yellow, next the distilled waters were added into the porcelain cup until volume reached $12.5 \mathrm{~mL}$ (initial volume). The samples were poured into cuvettes then and nitrate concentration was measured by UV Visible with a wavelength of $410 \mathrm{~nm}$ [14].

\section{Ammonium Method}

Methods of analysis in accordance with ammonium SNI 06-2479-1991 use the following steps. Water samples taken as much as $12.5 \mathrm{~mL}$ and put into a beaker glass $50 \mathrm{~mL}$. Solution of 0.5 $\mathrm{ml}$ Nessler as much added to in a beaker glass, a beaker glass then is shaking in order to make the perfect solution and let sit for approximately 30 minutes. A sample cuvet is then inserted into the measure by using UV Visible Spectrophotometer with a wavelength of $425 \mathrm{~nm}$ [15].

\section{Phosphate Method}

Phosphate levels can be calculated in spectrophotometry, the steps undertaken in this analysis is the water sample taken approximately $50 \mathrm{~mL}$ and then inserted into a beaker glass. Added 1 drop indicator phenolftalin (in case of change of color to pink, then added $\mathrm{H}_{2} \mathrm{SO}_{4}$ drop by drop until the color is gone). Added $0.5 \mathrm{gram}$ $\mathrm{K}_{2} \mathrm{~S}_{2} \mathrm{O}_{8}$ and boiled on top of the hot plate until the remaining volume $\pm 10 \mathrm{~mL}$. Samples are cooled and diluted with aquades up to volume 30 $\mathrm{ml}$. Next, added 1 drop indicator phenolftalin and neutralized with $\mathrm{NaOH}$ to pink color is shown. Again, melted $\mathrm{H}_{2} \mathrm{SO}_{4}$ until the pink color is vanished, then diluted to $100 \mathrm{~mL}$. Furthremore, $50 \mathrm{~mL}$ of volume is takken into a measuring flask. Moreover, added $8 \mathrm{ml}$ reactant combination, and then wait only for 15 minutes. Finally, the sample is inserted into its absorbance and measured with cuvet spectrophotometer with a wavelength of $880 \mathrm{~nm}$ [16]. 


\section{Growth Rate Calculation}

Growth during the study calculated based on the difference between the weight at the beginning of the study with a weight at the end of the research. The growth of sea grapes daily for 1 month cultivation can be calculated using the following formula [17]:

$$
g=\frac{W t-W 0}{t}
$$

Description:

$W t=$ weight of seedlings at the end of the study (g)

$\mathrm{W} 0=$ weight of seed research $(\mathrm{g})$

$\mathrm{g}=$ daily growth $\left(\mathrm{g} \cdot \mathrm{day}^{-1}\right)$

$\mathrm{t}=$ the number of days the experiment $(\mathrm{h})$

\section{Data analysis}

Analyze the life data using variance (ANOVA). The analysis was used to examine the effect of treatment, followed by the smallest real difference test (BNT) at the $5 \%$ test level.

\section{RESULT AND DISCUSSION}

Nitrate $\left(\mathrm{NO}_{3}{ }^{-}\right)$, Ammonium $\left(\mathrm{NH}_{4}{ }^{+}\right)$and Phosphate $\left(\mathrm{PO}_{3}{ }^{-}\right)$Content

From the soaking results, the higher waste dosage the higher Nitrate value. The detail can be seen in the Table 1 below.

Table 1. Nitrate, Ammonium and Phosphate Content (ppm) on different content

\begin{tabular}{cccc}
\hline doses $\left(\mathrm{g} \cdot \mathrm{L}^{-\mathbf{1}}\right.$ ) & $\mathbf{N O}_{3}{ }^{-}$ & $\mathbf{N H}_{4}{ }^{+}$ & $\mathbf{P O}_{3}{ }^{-}$ \\
\hline 0 & 2.64 & 1.63 & 0.73 \\
2 & 4.33 & 2.89 & 1.62 \\
4 & 4.50 & 3.22 & 1.85 \\
6 & 4.58 & 3.34 & 2.03 \\
\hline
\end{tabular}

Based on Tabel 1, it was obtained that the Nitrate content was different in each treatment, where various values can be caused by several factors. The factors that may affect the decomposition of organic substances were $\mathrm{C} / \mathrm{N}$ ratio, $\mathrm{pH}$, temperature and $\mathrm{DO}$ [18]. Comparison of Nitrate content, Ammonium and Phosphate is the basis of water quality, where the highest Nitrate value reaches $4.58 \mathrm{ppm}$. Comparing with standard quality of water quality, it is classified as polluted, because the tolerance limit of nitrate value in pond is not more than $0.5 \mathrm{ppm}$ [19]. Nitrogen in seawater consists of various compounds, but there are only three compounds containing toxic for fish and other organisms, namely ammonia $\left(\mathrm{NH}_{3}{ }^{-} \mathrm{N}\right)$, nitrite $\mathrm{NO}_{2}{ }^{-} \mathrm{N}$ and nitrate $\left(\mathrm{NO}_{3}{ }^{-} \mathrm{N}\right)$ [20]. However, for the crop, the high value is needed which will be a good nutrient for growth $C$. lentillifera [21].
Here, the value of ammonium with the largest value of $3.34 \mathrm{ppm}$ is obtained. It is a very good value for growth Caulerpa lentillifera. Because ammonium is needed for the process of protein formation in plants, ammonium serves as a support when plants lack $\mathrm{N}$ elements in the water. This ammonium is classified as a form of ammonium nitrogen [22]. Absorption of nitrogen by plants can be almost entirely in the form of ammonium or nitrate. Ammonium is used to be the main source for the growth in agriculture and most of the natural environment.

Meanwhile, the value of phosphat with the highest value of $2.03 \mathrm{ppm}$ is observed. This means water has a very high fertility rate, because waters with high fertility levels have phosphate levels of 0.51-1 ppm, medium fertility levels have levels of phosphate 0.2-0.5 ppm and a low fertility rate of $0-0.2 \mathrm{ppm}$. The main function of the phosphate element is to accelerate the growth of the root semia, accelerate and strengthen the growth of young plants into adulthood, accelerate flowering and ripening and increase seed production [23].

\section{Growth Rate of Caulerpa lentillifera}

The results obtained by the heavy growth of sea grapes are shown in Table 2. Table 2 is the results of the average daily growth, where this growth indicates the solid waste can be used as fertilizer for each treatment. The difference of growth is due to the absorption of nutrients in each treatment differently. In the $C$ treatment where the nutrient (Table 1) produced is greater than the other treatments resulting in an average daily growth 3.64 g.day ${ }^{-1}$. Whereas in the treatment $\mathrm{K}$ only 0.18 g.day ${ }^{-1}$. Therefore, the greatest growth obtained in the treatment of $\mathrm{C}$ which is needed more than other treatments.

Table 2. Growth Rate of $C$. lentillifera During Cultivation

\begin{tabular}{cc}
\hline $\begin{array}{c}\text { Doses Treatment } \\
\text { (g. } \text { - }^{-1} \text { ) }\end{array}$ & $\begin{array}{c}\text { Average growth } \\
\text { (g.day }^{-1} \text { ) }\end{array}$ \\
\hline K (0) & 0.18 \\
A (2) & 0.63 \\
B (4) & 1.87 \\
C (6) & 3.64 \\
\hline
\end{tabular}

The growth increases along with the increasing of the dose given (Fig. 2). The growth of Sea Grape can be accelerated by the addition of fertilizers in cultivation. Growth could be spurred by the addition of elemental Nitrogen $(\mathrm{N})$ and Posphate $(P)$, since both of these elements are the essential nutrients for algae [24]. 


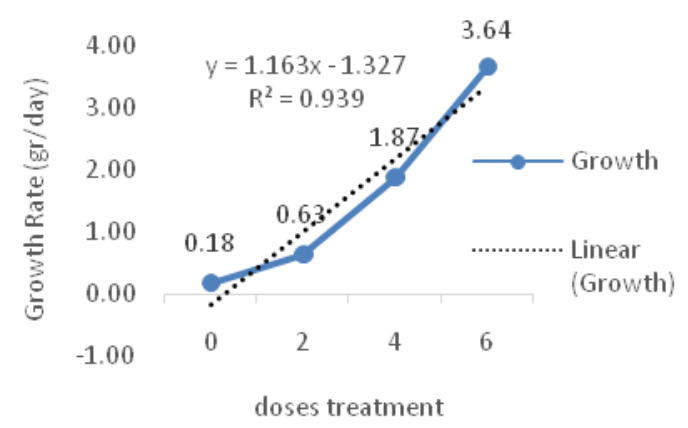

Figure 2. Growth Rate of Caulerpa lentillifera

Figure 2 shows the daily growth rate of $C$. lentillifera using various doses treatments. This can be proved that the difference of doses of solid waste ponds shrimp produces various growth rates of seedlings of sea grape (Fig. 2). Here, the higher dosage gives the growth rate increasing. Moreover, use the regression the function is obtained $y(x)=1.1631 x-1.3274$, where $y(x)$ and $x$ denote the growth rate functions and doses treatment respectively.

\section{pH Water}

Based on the observations that have been made during the study, the range of the $\mathrm{pH}$ is 6.4 -8 . The degree of acidity is good for the growth of algae is between 6-9 with optimal range 6.38.2 [25]. This condition describes that any algae have different torelansi towards a $\mathrm{pH}$. According to [26] States that the increase in $\mathrm{pH}$ values will affect the lives of algae and aquatic tendencies have a high acidity level due to the entry of large quantities of organic waste. The number of nitrification is very closely related to the $\mathrm{pH}$ levels. The longer soaking nitrates will soften that also comes with a decrease in $\mathrm{pH}$. $\mathrm{PH}$ changes depending on the process of amonifikasi and nitrification of nitrogen into ammonium and nitrate. The reaction of nitrate formation will free $\mathrm{H}^{+}$resulting $\mathrm{pH}$ in being dropped [27].

\section{CONCLUSION}

The results showed that solid waste shrimp ponds can be used as fertilizer to meet the needs of $C$. lentillifera for growth. Where nutrient obtained from the immersion of nitrate, ammonium and phosphate in the treatment with a doses of $6 \mathrm{~g}$. $\mathrm{L}^{-1}$ has a good value to grow $C$. lentillifera.

\section{REFERENCES}

[1] Siti, D., Nancy, H. Budiastuti. 2008. Absorpsi polutan amoniak di dalam air tanah dengan memanfaatkan tanaman Eceng Gondok
(Eichornia crassi). Jurnal Spektrum Teknologi. 15(2).

[2] Lacerda, L.D., A.G. Vaisman, L.P. Maia, C.A.R. de Silva, E.M.S. Cunha. 2006. Relative importance of nitrogen and phosphorus emmisions from shrimp farming and other anthropogenic sources of six estuaries along the NE Brazilian coast. Aquaculture. 253. 433-446.

[3] Nur, A. 2011. Manajemen pemeliharaan Udang Vaname. General Directorate of Fisheries Culture, BBPBAP Jepara. Center of Fisheries and Marines. Jakarta.

[4] Tangguda, S., A. Diana, W.E. Arning. 2015. Utiliation of solid waste from White Shrimp (Litopenaeus vannamei) farm on the growth and Chlorophyll content in Chlorella sp. J. Life Sci. Biomed. 5(3). 81-85.

[5] Paul, N.A., dN. Rocky. 2008. Promise and pitfalls of locally abundant seaweeds as biofilters for integrated aquaculture. Jurnal Aquaculture. 281. 49-55.

[6] Hanafi, A. 2007. Teknik produksi anggur laut Caulerpa lentillifera. Proceeding of National Symposium of Research Results on Marine and Fisheries. Indonesian Institute of Science (LIPI). Jakarta. 12-15.

[7] Badjoeri, M., Lukman. 2010. Distribusi dan kelimpahan populasi bakteri hetrotrofik di Danau Toba. Limnologi. 41. 88-97.

[8] Crab, R., Y. Avnimelech, T. Defoirdt, P. Bossier, W. Verstraete. 2007. Nitrogen removal techniques in aquaculture for a sustainable production. Aquaculture. 270. 114.

[9] Utomo, N.B.P., Winarti, A. Erlina. 2005. Pertumbuhan Spirulina platensis yang dikultur dengan pupuk inorganik (Urea, TSP, dan ZA) dan kotoran ayam. Jurnal Akuakultur Indonesia. 4(1). 41-48.

[10] Siswanto, D., I. Mustofa, G. Ekowati, M. Imam, E. Purnomo. 2011. Biosistem pertanian apel lokal Malang. J. Exp. Life Sci. 1(2). 56-110.

[11] Nugroho, Y.A., Y. Sugito, L. Agustina, Soemarno. 2013. Kajian penambahan dosis beberapa pupuk hijau dan pengaruhnya terhadap pertumbuhan tanaman Selada (Lactuca sativa L). J. Exp. Life Sci. 3(2). 4553.

[12] Guo, H., J. Yao, Z. Sun, D. Duan. 2014. Effects of salinity and nutrients on the growth and chlorophyll fluorescence of Caulerpa lentillifera. Chin. J. Oceanol. Limnol. 33(2). 410-418. 
[13] Boyd, C.E. 1986. Water quality management for pond fish culture. Elselvier Scientific Publishing Company. Amsterdam.

[14] Kjeldahl, J. 1883. A new method for the estimation of nitrogen in organic compounds. Z. Anal. Chem. 22. 366-372.

[15] BSN. 1991. Air, metode pengujian kadar amonium dengan alat spektrofotometer secara Nessler, SNI-06-2479-1991. Nationa Standard Office. Jakarta.

[16] Olsen, S.R., C.V. Cole, F.S. Watanabe, L.A. Dean. 1954. Estimation of available phosphorus in soils by extraction with sodium bicarbonate. US Government Printing Office. Washington DC.

[17] Effendie, M.I. 1997. Biologi perikanan. Yayasan Pustaka Nusantara. Yogyakarta.

[18] Yuningsih, H.D., P. Soedarsono, S. Anggoro. 2014. Hubungan bahan organik dengan produktivitas perairan pada kawasan tutupan eceng gondok, perairan terbuka dan keramba jaring apung di Rawa Pening Kabupaten Semarang Jawa Tengah. Diponegoro Journal of Maquares. 3(1). 3743.

[19] Undu, M.C., Makmur, S. Rachman. 2014. Studi pendahuluan laju efflux nutrien sedimen di tambak udang Litopenaeus vannamei super intensif. Proceeding of Forum on Aquaculture Technology Innovation 2014.

[20] Manikandan, K, T. Viruthagiri. 2010. Optimization of $\mathrm{C} / \mathrm{N}$ ratio of the medium and Fermentation conditions of Ethanol Production from Tapioca Starch using Co Culture of Aspergillus niger and Sachormyces cerevisiae. Int. J. ChemTech Res. 2(2). 947-955.

[21] Paul, N., A.N. Neveux., M. Magnusson, R.D. Nys. 2013. Comparative production and nutritional value of "sea grapes" - the tropical green seaweeds Caulerpa lentillifera and C. racemosa. J. Appl. Phycol. DOI 10.1007/s10811-013-0227-9.

[22] Howitt, S.M., M.K. Udvardi. 2000. Structure, function and regulation of ammonium transporters in plants. Biochimica et Biophysica Acta (BBA)-Biomembranes. 1465(1-2). 152-170.

[23] Fahrur, M., Makmur, C.U. Muhammad. 2014. Konsentrasi nitrogen terlarut dan fosfat dalam tambak Udang Vaname (Litopenaeus vannamei) sistem super intensif. Proceeding of Forum on Aquaculture Technology Innovation 2014.
[24] Carpenter, E.J., Capone, D.G. 1983. Nitrogen in the marine environment. Academic Press. $574.52636900 \mathrm{p}$.

[25] Syahputra, Y. 2005. Pertumbuhan dan kandungan karaginan Budidaya Rumput Laut Eucheuma cattonii pada Kondisi Lingkungan yang Berbeda dan Perlakuan Jarak Tanam di Teluk Lhok Seudu. Master Thesis. Graduate School, Bogor Agricultural University. Bogor.

[26] Luning, K. 1990. Seaweed: their environment, biogeography and ecophysiology. Jhon Wiley \& Sons, Inc. New York.

[27] Nainggolan, G.D., Suwardi, Darmawan. 2009. Pola pelepasan nitrogen dari pupuk tersedia lambat (slow release fertilizer) urea-zeolit-asam humat. Jurnal Zeolit Indonesia. 8(2). 89-96. 